\title{
Editorial:
}

\section{Roma Communities and COVID-19}

\section{Deniz Eroğlu Utku ${ }^{1}$}

On behalf of the editorial team of the Journal of Gypsy Studies, I am pleased to introduce the third volume. As advertised on the website, Journal of Gypsy Studies invites submissions in all disciplines, including (but not limited to) history, sociology, anthropology, political science, economics, law, musicology, cinema, literature, psychology, and linguistics. Contributions on under-researched regions where sizeable Gypsy populations live are particularly welcome, especially the Middle East, Africa, and Asia.

This issue of the Journal of Gypsy Studies coincided with the turmoil caused by global Covid-19 pandemic. The World Health Organisation has reported millions confirmed cases and deaths all around the world over the last two years (WHO, 2020). This is the tip of the iceberg; the pandemic has also had increasing economic and social consequences for many. Vulnerable groups have been drastically affected by the Covid-19 as IFRC, OCHA and WHO warned that "marginalized people become even more vulnerable in emergencies" (IFRC OCHE and WHO, 2020). In these reports, women, the elderly, adolescents, youth, and children, persons with disabilities, indigenous populations, refugees, migrants, and minorities are underlined as groups having the highest degree of socio-economic marginalisation. The same report also suggests which populations are most at risk. Accordingly, those that "depend heavily on the informal economy; occupy areas prone to shocks; have inadequate access to social services or political influence; have limited capacities and opportunities to cope and adapt; and, limited or no access to technologies" are somewhat vulnerable (IFRC OCHE and WHO, 2020).

\footnotetext{
${ }^{1}$ Dr Deniz Eroglu, Department of Public Administration, Trakya University, Edirne, Turkey. E-mail: denizeroglu@trakya.edu.tr.
} 


\section{Editorial}

It is quite important to add Roma communities to most at risk groups as significant studies show that many of them work in the informal sector (Belev, 2003; Korunovska \& Jovanovic, 2020; Lane et al., 2014; O'Higgins and Ivanov, 2006), many of them live in overcrowded neighbourhoods and houses (Korunovska and Jovanovic, 2020; Müller et al., 2020), they have difficulties accessing health care services and health insurance (Korunovska and Jovanovic, 2020; Kühlbrandt et al., 2014; Parekh and Rose, 2011) and they have limited access to sanitation and technologies (Anthonj et al., 2020; Davis and Ryan, 2016; Korunovska and Jovanovic, 2020; Müller et al., 2020) which are rather important during times like quarantine. This being the case, Roma communities are not those lucky ones who can follow all the rules to prevent the virus from spreading. Müller et al. states that "for hundreds of thousands of Roma people in Central and Southeast Europe, it is all impossible" (Müller et al., 2020).

Moreover, Roma groups face scapegoating and accusations of spreading the virus. Bulgaria, for instance, applied coronavirus lockdown in Roma neighbourhoods while this kind of measure was not taken for other districts (Krasimirov and Tsolov, 2020). The Slovak government is another one that sealed off entire communities to avoid the spread of disease (Holt, 2020). Even discriminatory health treatment in this country is reported (Korunovska and Jovanovic, 2020). Therefore, Pfohman and Hackl seems quite right in their claim that the "Roma and Traveller community has been enormously affected by the economic and social fall-out provoked by Covid-19" (Pfohman and Hackl, 2020). The deliberate marginalization and stigmatization of Roma communities in some countries were criticized by both international organizations and the Council of Europe, who asked for fair treatment for these groups (Amnesty International, 2020; Council of Europe, 2020).

Living with the coronavirus pandemic shows once again that Roma groups are one of the primary scapegoats for society's problems although they are more likely to suffer from these problems. At this point, shedding light on the lives and vulnerabilities of the Roma community is rather important to break stereotypes and prejudice as well as to get the attention of authorities to find solutions to existing problems.

In this issue, we present a study on invisible Roma mobility and a review of Alexandra Parrs book on Gypsies in contemporary Egypt.

\section{References}

Amnesty International. (2020). Slovakia: Roma Must not be Further Stigmatised During COVID-19. Retrieved 05.06.2020 from https://http://www.amnesty.org/ en/ documents/eur72/2110/2020/en/ 
Anthonj, C., Setty, K. E., Ezbakhe, F., Manga, M. and Hoeser, C. (2020). A systematic review of water, sanitation and hygiene among Roma communities in Europe: Situation analysis, cultural context, and obstacles to improvement. International Journal of Hygiene and Environmental Health, 226, 113506.

Belev, B. (2003). The Informal Economy in the EU Accession Countries: size, scope, trends and challenges in the process of EU enlargement: Csd. (Centre for the Study of Democracy).

Council of Europe. (2020). Governments must ensure equal protection and care for Roma and Travellers during the COVID-19 crisis. Retrieved 04.06.2020from https://http://www.coe.int/en/web/ commissioner/-/governments-must-ensure-equal-protection-and-care-for-roma-and-travellers-duringthe-covid-19-crisis

Davis, M. F. and Ryan, N. (2016). Inconvenient human rights: Access to water and sanitation in Sweden's informal Roma settlements. Raoul Wallenberg Institute, Sodertörn University, and NuLawLab (April 2016).

Holt, E. (2020). COVID-19 lockdown of Roma settlements in Slovakia. The Lancet Infectious Diseases, 20(6), 659.

Korunovska, N. and Jovanovic, Z. (2020). Roma in the Covid-19 Crisis. Retrieved 05.06.2020, from https://reliefweb.int/sites/reliefweb.int/files/resources/ Roma \%20in $\% 20$ the $\% 20$ COVID-19\%20 crisis $\% 20-\% 20$ An $\% 20$ early $\% 20$ warning $\% 20$ from $\% 20$ six $\% 20$ EU $\% 20$ Member $\% 20$ States.pdf

Krasimirov, A. and Tsolov, T. (2020). Bulgaria's Roma fear coronavirus lockdowns leave them with no means to live. Retrieved 03.06.2020, from https://http://www. reuters.com/article/us-healthcoronavirus-bulgaria-roma/bulgarias-roma-fear-coronavirus-lockdowns-leave-them-with-no-means-tolive-idUSKBN21Z362

Kühlbrandt, C., Footman, K., Rechel, B., and McKee, M. (2014). An examination of Roma health insurance status in Central and Eastern Europe. The European Journal of Public Health, 24(5), 707-712.

Lane, P., Spencer, S., and Jones, A. (2014). Gypsy, traveller and Roma: experts by experience.

Müller, S., Tair, F., Ibishi, B., and Gracanin, D. (2020). Roma: Europes Neglected Coronavirus Victıms. Balkaninsights. Retrieved 14.06.2020, from https://balkan insight.com/2020/04/01/roma-europesneglected-coronavirus-victims/

O'Higgins, N. and Ivanov, A. (2006). Education and employment opportunities for the Roma. Comparative Economic Studies, 48(1), 6-19.

Parekh, N. and Rose, T. (2011). Health inequalities of the Roma in Europe: a literature review. Cent Eur J Public Health, 19(3), 139-142.

Pfohman, S. and Hackl, T. (2020). The Roma are among most threatened by coronavirus in Europe. Euractive.

IFRC, OCHA, and WHO. (2020). COVID-19: How to include marginalised and vulnerable people inrisk communication and community engagement. Retrieved 3.06.2020, from https://reliefweb.int/ sites/ reliefweb.int/files/resources/COVID-19_CommunityEngagement_130320.pdf

UN News. (2020). World Health Organization: Coronavirus must generate 'solidarity not stigma'. Retrieved 05.06.2020, from https://news.un.org/en/story/ 2020/02/1057431

WHO. (2020). WHO Coronavirus Disease (COVID-19) Dashboard. from Retrieved 05.06.2020, https:// covid19.who.int/?gclid=Cj0KCQjwuJz3BRDTARIsAMg-Hx Wee46fqzeNOna9-IqxkVwfZkg L_Thp XXx8-G1vq 4paZAhX0obnqEAaAh8VEALw_wcB 